\title{
Penampilan Kandungan Protein Dan Kadar Lemak Susu Pada Sapi Perah Mastitis Friesian Holstein
}

\author{
Puguh Suryowardojo \\ Jurusan Teknologi Hasil Peternakan, Fakultas Peternakan, Universitas Brawijaya
}

\begin{abstract}
Abstrak
Penelitian ini dilaksanakan di peternakan wilayah kerja Proyek Peternakan Sapi Perah GKSI Jawa Timur di Desa Sawiran, Kecamatan Purwodadi, Kabupaten Pasuruan dan di Laboratorium Ternak Perah Fakultas Perternakan Universitas Brawijaya. Tujuan penelitian ini adalah untuk mengetahui penampilan kadar protein dan kadar lemak susu pada tingkat mastitis yang berbeda pada sapi perah. Hasil penelitian ini diharapkan dapat dimanfaatkan sebagai informasi tentang pentingnya melakukan pencegahan penyakit mastitis sebagai salah satu faktor penyebab perubahan kadar protein dan kadar lemak susu yang dihasilkan. Materi penelitian adalah sampel susu dari kuartir ambing 30 ekor sapi perah (120 puting) laktasi, dengan bulan laktasi 2 sampai 3 dan tingkat laktasi 2 sampai 3. Metode penelitian yang digunakan adalah study kasus. Observasi langsung dilapang yang dilakukan untuk mengetahui tingkat mastitis pada sapi perah berdasarkan California Mastitis Test (CMT). Dan untuk menguji kadar protein dan kadar lemak dilakukan di Laboratorium Ternak Perah. Hasil penelitian menunjukkan bahwa puting sapi perah sampel berada pada tingkat nol sebanyak 5 ekor $(16,67 \%)$ dan yang terkena mastitis sebanyak 25 ekor $(83,33 \%)$. Tingkat mastitis dan protein serta lemak susu mempunyai hubungan yang linier negatif yang sangat nyata $(p \leq 0,01)$. Berdasarkan persamaan regresi semakin tinggi tingkat mastitis maka kadar protein dan lemak susu semakin menurun. Kesimpulan dari penelitian ini adalah semakin tinggi nilai mastitis maka kadar protein dan kadar lemak susu semakin menurun sebesar $53 \%$ dan $33 \%$. Dari penelitian ini dapat disarankan agar peternak lebih menjaga kesehatan lingkungan untuk mencegah berjangkitnya penyakit mastitis pada peternakan tersebut.
\end{abstract}

Kata Kunci: Friesian Holstein, mastitis, lemak susu, protein

\begin{abstract}
The study was carried out in the GKSI livestock of dairy cows East Java in Sawiran village, Pasuruan Regency and also at the Laboratory of Dairy Animal, Faculty of Animal Husbandry Brawijaya University. The objective of the study was to find out the performance of mastitis level in protein and fat content of milk dairy cows in GKSI farm East Java. It was expected the results of this study could be used as an information on the importance role of preventing mastitis disease as one of the factor cause of change of protein and fat content of milk production. The materials observed were milk samples from 30 milking cows, with two to third month of lactation and two to third stage of lactation. The method of research is case study. Field observation have been done to determind mastitis in cadence based on California Mastitis Test (CMT). The protein content of milk was determined using formol titration method and fat content of milk was determited by gerber method at the Laboratory of dairy animal.. The data were analysed using simple Corelation and Regression. It was found that 5 cows (16.67\%) were in mastitis level zero and 25 cows (83.33\%) infected of mastitis. Mastitis level was linerly correlated highly significantly $(p \leq 0.01)$. According to regression expressed if mastitis be higher the protein procentages and milk fat can be lower. It was conclude that mastitis level significantly decreased protein and fat content of milk by $53 \%$ and $33 \%$ respectively. The dairy cows were mastitis infected are $83.33 \%$. From this research can be suggested that farmers should be able to keep healthy environment in order to protect mastitis diseases in their farm.
\end{abstract}

Keywords: Fat Milk, Frisian Holstein, Mastitis, Protein

\section{PENDAHULUAN}

Peternakan sapi perah merupakan salah satu penggerak ekonomi dikawasan pedesaan, karena peternakan ini dapat menyediakan lapangan

\footnotetext{
* Alamat korespondensi:

Puguh Suryowardojo

Email : suryowardojo_puguh@yahoo.com

Alamat : Jurusan Teknologi Hasil Peternakan, Fakultas Peternakan, Universitas Brawijaya, Jl. Veteran, Malang, 65145
}

pekerjaan kepada petani ternak. Dewasa ini di negara-negara yang sudah maju maupun di negara-negara yang sedang berkembang (termasuk di Indonesia), sapi perah merupakan sumber utama penghasil susu yang mempunyai nilai gizi tinggi. Walaupun ada pula susu yang dihasilkan oleh ternak lain misalnya kerbau, kambing, kuda dan domba, akan tetapi penggunaannya dimasyarakat tidaklah sepopuler susu sapi perah. Sapi perah mempunyai karakteristik yang lebih baik dari ternak lain 
dalam hal efisiensi mengubah pakan menjadi protein hewani dan kalori. Efisiensi sapi perah dalam mengubah pakan menjadi protein hewani dan kalori, hingga saat ini belum tertandingi oleh hewan jenis lainnya. Dengan produksi susu 4.500 liter pertahun, sapi perah mampu menyediakan zat - zat makanan bagi manusia sama dengan dua ekor sapi jantan kebiri yang beratnya masing - masing $500 \mathrm{~kg}$. Dengan pertimbangan tersebut maka dapat dikatakan bahwa sapi perah merupakan ternak unggul dan efektif mempunyai peran dalam mencukupi kebutuhan protein hewani bagi masyarakat [1].

Faktor penghambat produksi susu pada usaha peternakan sapi perah adalah timbulnya kasus penyakit pada ternak. Penyakit yang paling sering muncul dalam usaha ternak perah adalah Mastitis. Mastitis atau radang kelenjar susu merupakan kasus yang sering terjadi pada peternakan sapi perah. Mastitis sangat merugikan peternak, karena sapi perah yang terkena mastitis akan mengalami penurunan produksi susu, dan kualitas susu yang dihasilkan juga rendah. Selain itu adanya penyakit mastitis akan menambah biaya perawatan dan biaya pengobatan untuk kelangsungan produksinya. Tingginya kasus mastitis sering terjadi akibat manajemen pemeliharaan yang kurang baik.

Mastitis adalah suatu peradangan pada tenunan ambing yang dapat disebabkan oleh mikroorganisme, zat kimia, luka termis ataupun luka karena mekanis. Peradangan ini dapat mempengaruhi komposisi susu antara lain dapat menyebabkan bertambahnya protein dalam darah dan sel darah putih di dalam tenunan ambing, serta menyebabkan penurunan produksi susu [2]. Umumnya radang ambing disebabkan oleh bakteri Staphylococcus aureus dan Streptococcus agalactiae, dan bakteri tersebut dapat berpindah dari kuartir yang terinfeksi ke kuartir yang sehat dengan melalui tangan pemerah atau kain pembersih ambing serta alatalat lainnya [3].

Mastitis pada sapi perah ada dua macam, yakni mastitis subklinis dan klinis [1]. Selama ini pengetahuan peternak hanya terbatas pada mastitis klinis, karena perubahan susu yang dihasilkan dapat diamati secara langsung, yaitu susu terlihat menggumpal atau cair, dan terdapat darah atau nanah. Sedangkan mastitis subklinis tidak dapat dilihat perubahannya secara langsung, sehingga perlu pengujian khusus, salah satunya dengan metode California Mastitis Test (CMT).
Mastitis pada sapi perah telah mengakibatkan kerugian yang sangat besar bagi peternak, karena disamping jaringan ambing ternak yang bersangkutan rusak juga susu yang diproduksi tidak dapat dijual, karena telah rusak dan tercemar oleh mirkoorganisme. Keadaan resistensi sapi perah terhadap mastitis ini sangat bervariasi, sehingga masih dimungkinkan dilakukan seleksi terhadap induk-induk yang resisten [4].

Penelitian ini dilakukan di Proyek Sapi Perah FH GKSI Jawa Timur berada di Desa Sawiran Kecamatan Purwodadi Kabupaten Pasuruan merupakan proyek pengembangan sapi perah sebagai percontohan Koperasi Persusuan di Jawa Timur yang berdiri sejak tahun 2000. Lokasi tersebut terletak kira-kira $12 \mathrm{~km}$ sebelah Timur dari jalan raya.

Rata-rata suhu kandang di peternakan ini adalah sekitar $19,3^{\circ} \mathrm{C}$ pada pagi hari, $25,9^{\circ} \mathrm{C}$ pada siang hari, dan $22,9^{\circ} \mathrm{C}$ pada sore hari. Umumnya sapi perah yang dipelihara di Indonesia adalah bangsa sapi FH. Sapi tersebut berasal dari Belanda yang memiliki lingkungan hidup dengan temperatur antara $13^{\circ} \mathrm{C}$ sampai $23^{\circ} \mathrm{C}$ [5].

Rata-rata kelembaban relatif kandang adalah sekitar $61,37 \%$ pada pagi hari, $76,17 \%$ pada siang hari, dan $58,30 \%$ pada sore hari. Kelembaban udara tersebut termasuk cukup ideal bagi pemeliharaan sapi perah laktasi adalah $60-80 \%$. Kelembaban yang tinggi dapat merangsang tumbuhnya mikroorganisme penyebab penyakit ternak. Ternak yang terserang penyakit akan mengalami penurunan nafsu makan dan berakibat pada menurunnya kecepatan pertumbuhan [6].

Luas areal peternakan secara keseluruhan adalah 1,5 Ha. Jarak kandang dengan rumah penduduk terdekat sekitar 50 meter. Jarak ini cukup ideal untuk sebuah peternakan karena tidak begitu mengganggu lingkungan sekitar.

Penelitian ini bertujuan untuk mengetahui perorman kandungan protein dan kadar lemak susu pada sapi perah yan terinfeksi mastitis. Hasil penelitian diharapkan dapat dimanfaatkan khususnya sebagai bahan informasi kepada petani peternak sapi perah tentang performan kandungan protein dan kadar lemak susu pada sapi perah yang terinfeksi mastitis.

\section{METODE PENELITIAN \\ Lokasi Penelitian}

Penelitian lapang dilakukan di Proyek Sapi Perah FH GKSI Jawa Timur Desa Sawiran Kecamatan Purwodadi Kabupaten Pasuruan. 
Pengukuran kandungan protein dan kadar lemak susu dilaksanakan di Laboratorium Ternak Perah, Fakultas Peternakan Universitas Brawijaya.

\section{Metode dan Materi Penelitian}

Metode penelitian menggunakan metode studi kasus dan penentuan sampel sapi perah secara purposive sample. Purposive sample adalah semua sapi perah yang termasuk dalam kriteria yang telah ditentukan, yaitu sapi perah dengan tingkat laktasi $2-3$, dan bulan laktasi 2 3 yang dapat dipakai sebagai anggota sampel sebanayak 30 ekor.

Pengambilan sampel susu diambil pada waktu pemerahan pagi dan sore hari. Pengujian CMT dilaksanakan secara langsung di lapangan, sehingga apabila dilakukan pada sore hari dengan cahaya yang cukup terang akan didapat hasil yang akurat. Untuk uji mastitis, sebanyak dua pancaran pertama dibuang, pancaran kedua dan pancaran ketiga dari masing-masing puting ditampung pada paddle kemudian ditambahkan reagen yang kira-kira sama jumlahnya. Reagen tersebut terdiri dari alkyl aryl sulfonate $3 \%$, $\mathrm{NaOH} 1,5 \%$ dan indicator Broom Kresol Purple. Setelah ditambahkan reagen, paddle dan isinya diputar perlahan-lahan secara horizontal selama 10 detik.

Pengambilan sampel susu dari masing-masing sapi perah dimasukkan ke dalam botol sampel, selanjutnya di bawa ke laboratorium untuk uji kualitas susu, salah satunya uji kandungan protein dan kadar lemak susu.

\section{Penentuan Kandungan Protein dan lemak Susu}

Penentuan kandungan protein dilakukan dengan cara formol titration, menurut Anonimous [7] dan Prawesthirini dkk. [8]. Penentuan kadar lemak susu dengan metode gerber menurut SNI [9].

\section{Penentuan Tingkat Mastitis}

Penentuan tingkat mastitis menurut pendapat Subronto [10] seperti pada Tabel 1.

\section{Analisis Data}

Metode yang digunakan untuk mengetahui keeratan hubungan antara nilai mastitis berdasarkan CMT dengan kadar protein dan lemak susu adalah dengan menggunakan analisis korelasi dan regresi sederhana dan untuk mengetahui besar pengaruhnya dengan koefisien determinasi $\left(R^{2}\right)$ [11] dan analisis ragam [12].
Tabel 1. Interpretasi berdasarkan CMT

\begin{tabular}{|c|c|c|c|}
\hline Simbol & Arti & Reaksi & $\begin{array}{c}\text { Estimasi } \\
\text { jumlah sel } \\
\text { per ml susu }\end{array}$ \\
\hline \multirow[t]{2}{*}{-} & Negatif & $\begin{array}{l}\text { Tidak ada tanda- } \\
\text { tanda presipitasi }\end{array}$ & $\begin{array}{l}<10.000- \\
200.000\end{array}$ \\
\hline & & Sedikit terjadi & \\
\hline \multirow[t]{2}{*}{$\mathrm{T}$} & Trace & presipitasi & 150.000- \\
\hline & & Presipitasi tampak & 500.000 \\
\hline \multirow[t]{2}{*}{1} & Positif & nyata, tetapi belum & 400.000- \\
\hline & lemah & $\begin{array}{l}\text { terbentuk gel } \\
\text { Campuran } \\
\text { mengental, }\end{array}$ & 1.500 .000 \\
\hline \multirow[t]{2}{*}{2} & Positif & terbentuk gel & $800.000-$ \\
\hline & nyata & $\begin{array}{l}\text { Gel yang } \\
\text { menyebabkan }\end{array}$ & 5.000 .000 \\
\hline \multirow[t]{2}{*}{3} & Positif & permukaan & lebih \\
\hline & Kuat & menjadi cembung & 5.000 .000 \\
\hline
\end{tabular}

\section{HASIL DAN PEMBAHASAN}

Mastitis pada Sapi Perah

Sapi perah yang mempunyai kemampuan mempertahankan produksi susu setelah mencapai puncak laktasi lebih baik dari pada sapi yang cepat turun produksi susunya, karena produksi susu sapi perah setiap harinya berangsur-angsur meningkat sampai puncak dalam waktu kurang lebih dua bulan setelah beranak, kemudian konstan sampai bulan laktasi ketiga, setelah itu produksi susu akan berangsurangsur turun sampai akhir laktasi [13].

Hasil pengujian mastitis dengan metode CMT pada susu sapi perah diperoleh bahwa sapi perah yang terkena mastitis sebanyak 25 ekor, lihat Tabel 2.

Tabel 2. Rata-rata nilai mastitis berdasarkan uji CMT pada susu sapi perah

\begin{tabular}{ccc}
\hline Rata-rata nilai Mastitis & Jumlah Sapi & (\%) \\
\hline 0 & 5 & 16.67 \\
0,25 & 1 & 3.33 \\
0,5 & 1 & 3.33 \\
0,75 & 2 & 6.66 \\
1 & 4 & 13.33 \\
1,25 & 2 & 6.66 \\
1,5 & 4 & 13.33 \\
1,75 & 1 & 3.33 \\
2 & 4 & 13.33 \\
2,25 & 3 & 10.00 \\
2,5 & 2 & 6.66 \\
3,75 & 1 & 3.33 \\
\hline
\end{tabular}

Terjangkitnya mastitis pada sapi perah dapat disebabkan oleh beberapa hal, antara lain:

1. Kebersihan tempat, peralatan dan kebersihan sapi yang biasanya kurang mendapat perhatian, hal ini terlihat dari sisa pakan yang masih tercecer dan kotoran sapi 
yang masih menempel pada dinding kandang.

2. Kebersihan sapi sebelum diperah yang belum dibersihkan atau dimandikan. Hal ini tidak sesuai dengan pendapat Anonimus [7] yang menyatakan bahwa sapi perah yang akan diperah harus dalam keadaan bersih, semua sapi yang akan diperah harus dimandikan terlebih dahulu seperti bagian-bagian lipatan paha, ambing dan puting.

3. Setelah pemerahan selesai, ambing dan puting tidak dibersihkan. Menurut Siregar [5] sebelum dan sesudah pemerahan ambing dan puting harus dicuci dengan air hangathangat kuku, khusus puting setelah dibersihkan harus sebaiknya dicelupkan ke dalam air yang telah dicampur dengan biocid.

4. Pemerahan puting yang tidak terinfeksi dan yang terinfeksi tidak dibedakan, puting yang terinfeksi terkadang dilakukan pemerahan terlebih dahulu, sehingga dapat menjadi penyebab tertularnya mastitis ke ternak yang sehat melalui tangan pemerah.

Mastitis dikenal sebagai infeksi atau peradangan pada ambing. Mastitis adalah suatu peradangan pada tenunan ambing yang dapat disebabkan oleh mikroorganisme, zat kimia, luka termis ataupun luka karena mekanis [2].

Mastitis pada sapi perah telah mengakibatkan kerugian yang sangat besar bagi peternak, karena disamping jaringan ambing ternak yang bersangkutan rusak juga susu yang diproduksi tidak dapat dijual karena telah rusak dan tercemar oleh mirkoorganisme. Keadaan resistensi sapi perah terhadap mastitis ini sangat bervariasi, sehingga masih dimungkinkan dilakukan seleksi terhadap induk-induk yang resisten [4]. Sesuai dengan pendapat diatas, Dinas Peternakan Jakarta Barat [14] berpendapat bahwa pencegahan mastitis dapat dilakukan melalui penerapan kebersihan kandang, badan sapi, peralatan, tukang perah dan penggunaan bahan-bahan antiseptik sebagai pencuci ambing pada saat sebelum maupun setelah pemerahan, pemerahan dilakukan secara tuntas, mengisolasi sapi yang terjangkit mastitis untuk segera dilakukan pengobatan. Selain itu perlu dilakukan pencelupan puting susu setelah pemerahan kedalam antiseptik selama kurang lebih 1 menit.

Hasil penelitian diperoleh bahwa adanya tingkat nol hasil pemeriksaan mastitis pada sapi perah menunjukkan adanya upaya pencegahan penyakit mastitis oleh pihak GKSI Jawa Timur.
Salah satu pencegahan penyakit ini adalah dengan melaksanakan tatalaksana yang baik pada kandang dan pemerahan serta sanitasi alatalat perah dan sekitar kandang, hal ini sesuai dengan pendapat Dinas Peternakan Jakarta Barat [14].

Terjadinya mastitis sapi perah sebanyak 25 ekor merupakan salah satu indikator manajemen pemerahan yang kurang baik. Menurut Sarwiyono dkk. [15], di Indonesia ada tiga cara pemerahan yang dapat dilakukan secara manual, yaitu : Whole hand, Knevelen dan Stripping atau Strippen. Proses pemerahan dapat diakhiri apabila susu sudah tidak dapat keluar lagi dari ambing atau jika kecepatan susu sudah sangat lambat, yaitu : 0,5 liter per menit.

Di karenakan mastitis pada tingkat SubClinical, tanda-tanda keabnormalan susu tidak dapat dilihat secara kasat mata, maka pada setiap ternak sapi perah perlu dilakukan uji secara rutin untuk mendeteksi kemungkinan terjangkitnya mastitis.

Menurut Hidayat dkk. [16] bahwa berdasarkan gejalanya dapat dibedakan antara mastitis klinis dan subklinis. Mastitis klinis meliputi :

- Akut, ditandai dengan ambing membengkak,panas, kemerahan, nyeri bila diraba dan perubahan fungsi. Dengan kondisi umum ternak tidak mau makan. Perubahan pada susunya yaitu susu memancar tidak normal, bening atau encer; kental, menggumpal atau berbentuk seperti mie; warna berubah menjadi semu kuning, kecoklatan, kehijauan, kemerahan atau ada bercak-bercak merah.

- Kronis, ditandai dengan ternak terlihat seperti sehat, ambing teraba keras, peot dan mengeriput serta puting peot.

Sedangkan mastitis sub klinis merupakan peradangan pada ambing tanpa ditemukan gejala klinis pada ambing dan air susu :

- Ternak terlihat seperti sehat : nafsu makan biasa dan suhu tubuh normal

- Ambing normal

- Susu tidak menggumpal dan warna tidak berubah

\section{Nilai Mastitis Berdasarkan Metode CMT dengan Kandungan Protein Susu \\ Hasil perhitungan yang menunjukkan kandungan protein susu sapi perah susu}


menurun dengan meningkatnya tingkat mastitis seperti pada Tabel 3.

Tabel 3. Rata-rata kandungan protein susu sapi perah sampel pada berbagai rata-rata nilai mastitis berdasarkan

\begin{tabular}{lccl}
\multicolumn{5}{c}{ nilai CMT } \\
\hline No & $\begin{array}{c}\text { Rata-rata nilai } \\
\text { mastitis }\end{array}$ & $\begin{array}{r}\text { Banyak } \\
\text { sampel }\end{array}$ & $\begin{array}{c}\text { Rata2 kdr protein } \\
\text { susu (\%) }\end{array}$ \\
\hline 1 & 0 & 5 & $3,80 \pm 2,50$ \\
2 & 0,25 & 1 & 3,13 \\
3 & 0,5 & 1 & 3,16 \\
4 & 0,75 & 2 & $3,13 \pm 3,10$ \\
5 & 1 & 4 & $2,89 \pm 2,54$ \\
6 & 1,25 & 2 & $2,87 \pm 2,86$ \\
7 & 1,5 & 4 & $2,81 \pm 2,02$ \\
8 & 1,75 & 1 & 2,27 \\
9 & 2 & 4 & $2,94 \pm 2,03$ \\
10 & 2,25 & 3 & $2,57 \pm 2,08$ \\
11 & 2,5 & 2 & $2,59 \pm 2,25$ \\
12 & 3,75 & 1 & 1,59 \\
\hline
\end{tabular}

Berdasarkan Tabel 3. diatas rata-rata kadar protein yang terendah terdapat pada sampel susu dengan rata-rata nilai mastitis 3,75 . Susu yang diperoleh dari sapi perah yang terkena mastitis akan mengalami penurunan kadar protein susu. Hal ini dapat disebabkan oleh adanya peradangan pada kelenjar susu akibat adanya pertumbuhan bakteri. Komponen susu termasuk didalamnya protein susu di bentuk di kelenjar susu yang terdiri dari alveolus. Setiap alveolus terdiri dari sel epithel yang merupakan sel-sel sekresi susu. Setelah mikroorganisme berhasil masuk ke dalam kelenjar, dalam waktu singkat akan membentuk koloni dan menyebar ke lobuli dan alveoli. Oleh karena adanya kerja mikroorganisme akan menyebabkan perubahan komposisi susu yang ada di dalam kelenjar susu hingga susu menjadi rusak [10]. Sesuai juga dengan pendapat Taylor [17] bahwa infeksi mastitis dapat menyebabkan kerusakan pada luar jaringan kelenjar susu, yang dikenal sebagai sel epitel. Di mana sintesis protein terjadi dalam sel epitel, dikontrol oleh gen yang mengandung bahan genetik yaitu DNA. Kerusakan ini meningkatkan ion sodium dan klorid yang dapat lepas ke dalam kelenjar susu. Peningkatan total protein dapat menyebabkan meningkatnya serum protein yang masuk ke dalam susu melalui darah, seperti halnya produksi susu menurun lebih cepat dibandingkan sintesis protein. Sintesis protein terjadi di ribosoma dimana terdapat mRNA yang dalam beberapa hal terikat dengan rRNA. Asam amino dibawa ketempat ikatan ini oleh tRNA aminoacyl-tRNA makin bertambah molekulnya. Antikodon dari tRNA mengenal kodon dan menempatkan asam amino pada posisi permulaan. Pada sat ribosom bergerak melelui kodon, suatu amino acyl tRNA yang baru bergerak menempati posisinya. Pada saat yang bersamaan ikatan peptide antara grup karboksil dari satu asam amino dan grup amino dari asam amino kedua terbentuk. Sesudah ikatan peptida terbentuk maka tRNA dibebaskan kedalam cytoplasma sehingga dapat mengikat asam amino lainnya. Pada sisi yang lain, kasein yang merupakan jenis protein yang lain akan menurun bila produksi susu menurun. Peningkatan serum protein diharapkan menutupi kekurangan akibat menurunnya kadar kasein.

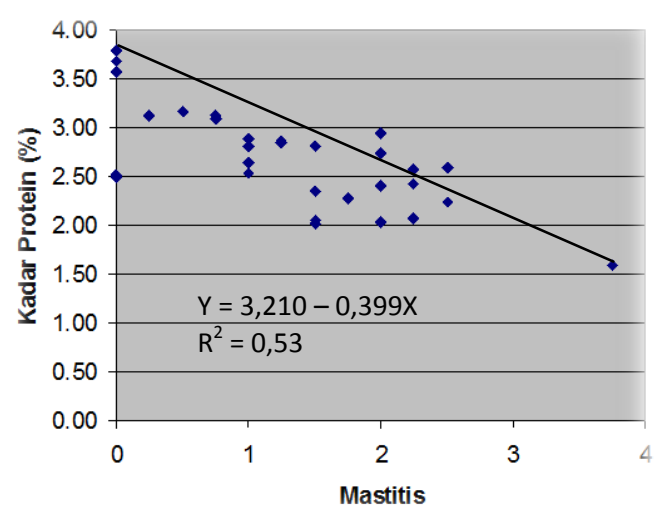

Gambar 1. Pengaruh antara rata-rata nilai mastitis terhadap kadar protein susu

Gambar 1 menunjukkan adanya pengaruh yang linier negatif antara tingkat mastitis dengan kadar protein susu yaitu $r=-0,726$ yang berarti bahwa semakin tinggi nilai mastitis maka kadar protein susu semakin rendah. Sedangkan koefisien determinasi menunjukkan ada tidaknya pengaruh mastitis terhadap kadar protein susu. Nilai $\mathrm{R}^{2}=53 \%$ berarti menurunnya kadar protein susu sapi perah di peternakan dipengaruhi oleh terjadinya mastitis sebesar $53 \%$.

Berdasarkan hasil analisis statistik dengan menggunakan metode korelasi dan regresi serta hasil analisis sidik ragam $\mathrm{F}$ hitung $>\mathrm{F}$ tabel menunjukkan bahwa adanya pengaruh yang sangat nyata antara mastitis dengan kadar protein susu. Adapun persamaan tersebut $\hat{Y}=$ 3,210 - 0,399X dapat dijadikan sebagai alat penduga nilai $Y$ (kadar protein susu), bila X (nilai mastitis) sudah diketahui.

\section{Nilai Mastitis Berdasarkan Metode CMT dengan Kadar Lemak Susu}

Hasil perhitungan menunjukkan bahwa kadar lemak susu sapi perah menurun dengan meningkatnya tingkat mastitis. Berdasarkan 
Tabel 4, rata-rata kadar lemak yang terendah terdapat pada sampel susu dengan rata-rata nilai mastitis 1,75 . Subronto [10], menyatakan bahwa setelah mikroorganisme berhasil masuk ke dalam kelenjar, mikroorganisme akan membentuk koloni yang dalam waktu singkat akan menyebar ke lobuli dan alveoli.

Tabel 4. Rata-rata kadar lemak susu sapi perah pada berbagai jumlah tingkat mastitis

\begin{tabular}{cccc}
\hline No & $\begin{array}{c}\text { Rata-rata } \\
\text { nilai mastitis }\end{array}$ & $\begin{array}{c}\text { Banyaknya } \\
\text { sampel }\end{array}$ & $\begin{array}{c}\text { Rata2 kdr } \\
\text { lemak susu (\%) }\end{array}$ \\
\hline 1 & 0 & 5 & $4,9 \pm 2,8$ \\
2 & 0,25 & 1 & 3,3 \\
3 & 0,5 & 1 & 3 \\
4 & 0,75 & 2 & $3,2 \pm 3,1$ \\
5 & 1 & 4 & $4,3 \pm 2,6$ \\
6 & 1,25 & 2 & $2,7 \pm 2,6$ \\
7 & 1,5 & 4 & $4,2 \pm 2,5$ \\
8 & 1,75 & 1 & 2,1 \\
9 & 2 & 4 & $2,8 \pm 2,3$ \\
10 & 2,25 & 3 & $2,8 \pm 2,3$ \\
11 & 2,5 & 2 & 2,6 \\
12 & 3,75 & 1 & 2,5 \\
\hline
\end{tabular}

Pada saat mikroorganisme sampai ke mukosa kelenjar, tubuh bereaksi dengan memobilisasikan leukosit. Karena adanya kerja mikroorganisme akan menyebabkan perubahan susu yang ada di dalam kelenjar mammae hingga susu menjadi rusak. Selanjutnya rusaknya kelenjar mammae akan merangsang timbulnya reaksi jaringan dalam bentuk peningkatan sel di dalam kelenjar susu. Oleh karena adanya radang maka produksi susu akan berkurang dan menyebabkan susunan susu mengalami penurunan, termasuk adanya penurunan kadar lemak susu. Sesuai juga dengan pendapat Shiddieqy [18] bahwa lemak susu dikeluarkan dari sel epitel ambing dalam bentuk globula lemak (fat globule) yang diameternya bervariasi antara 0,1 - 15 mikron. Globula lemak tersusun atas globula trigliserida yang dikelilingi membran tipis yang dikenal dengan Fat Globule Membran (FGM) atau membran globula lemak susu. Komponen utama dalam FGM adalah protein dan fosfolipid (phospholipid). FGM salah satunya berfungsi sebagai stabilisator globula lemak susu dalam emulsi dengan kondisi encer (aqueous) dari susu, karena susu sapi mengandung air sekira $87 \%$. Peradangan menyebabkan lambatnya sintesis lemak sehingga konsentrasi lemak turun dan juga berkurangnya produksi susu.

Gambar 2 menunjukkan adanya pengaruh yang linier negatif antara tingkat mastitis dengan kadar lemak susu yaitu $r=-0,576$ yang berarti bahwa semakin tinggi nilai mastitis maka kadar lemak susu semakin rendah. Sedangkan koefisien determinasi menunjukkan ada tidaknya pengaruh mastitis terhadap kadar protein susu. Nilai $\mathrm{R}^{2}=33 \%$ berarti menurunnya kadar lemak susu sapi perah di peternakan wilayah kerja Proyek Sapi Perah GKSI Jawa Timur dipengaruhi oleh terjadinya mastitis sebesar $33 \%$.

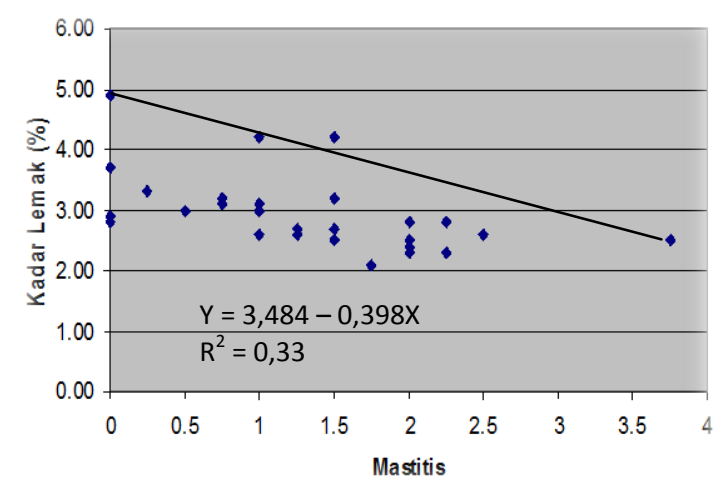

Gambar 2. Pengaruh antara rata-rata nilai mastitis terhadap kadar lemak susu

Berdasarkan hasil analisis statistik dengan menggunakan metode korelasi dan regresi serta hasil analisis sidik ragam $\mathrm{F}$ hitung $>\mathrm{F}$ tabel menunjukkan bahwa adanya pengaruh yang sangat nyata antara mastitis dengan kadar protein susu. Adapun persamaan tersebut $\hat{Y}=$ 3,484 - 0,398X dapat dijadikan sebagai alat penduga nilai $Y$ (kadar lemak susu), bila $X$ (nilai mastitis) sudah diketahui.

\section{KESIMPULAN DAN SARAN}

Hasil persentase sapi perah sample yang sehat dan terkena mastitis di peternakan sebesar 16,67 \% (5 ekor) dan 83,33\% (25 ekor). Mastitis mempengaruhi penurunan kadar protein susu sebesar $53 \%$ serta kadar lemak susu sebesar $33 \%$. Nilai mastitis mempunyai pengaruh yang linier negatif dengan kadar protein dan lemak susu, yaitu semakin tinggi nilai mastitis maka kadar protein dan lemak susu semakin menurun.

Dari hasil penelitian ini diketahui bahwa mastitis dapat menurunkan kadar protein dan lemak susu, sehingga disarankan kepada petani ternak sapi perah untuk menjaga kondisi lingkungan ternak perah, agar tidak mudah terinfeksi penyakit mastitis.

\section{DAFTAR PUSTAKA}

[1] Sudono A., Rosdiana F.R. dan Setiawan B.S., 2003. Beternak sapi perah secara intensif. Agromedia Pustaka. Jakarta.

[2] Saleh E. 2004. Dasar pengolahan susu dan hasil ikutan ternak. Program Studi Produksi Ternak Fakultas Pertanian. Universitas Sumatera Utara. 
[3] Sudono A. 1999. Ilmu produksi ternak perah. Fakultas Peternakan. Institut Pertanian Bogor, Bogor.

[4] Youngerman S.M., Oliver S.P., Saxton A.M., Edwards J.L., Schrick F.N., Davies C.J., dan Pighetti G.M. 2004. A novel candidate genetic marker for mastitis resistence in Jersey cattle. The University of Tennessee, Knoxville, TN.

[5] Siregar S. 1996. Sapi Perah: jenis, teknik pemeliharaan dan analisa usaha. Penebar Swadaya. Jakarta

[6] Santoso U. 1999. Prospek agribisnis penggemukan pedet. Penebar Swadaya. Jakarta.

[7] Anonimus. 1995. Petunjuk praktis beternak sapi perah. Coorperative Centre Denmark. GKSI Jawa Timur.

[8] Prawesthirini S., Lusiastuti A.M., Harijani M., Estoepangestie A.T.S., Effendi M.H. dan Siswanto H.P. 2001. Analisis kualitas susu dan daging. Fakultas Kedokteran Hewan Universitas Airlangga. Surabaya

[9] SNI. 1992. Metode pengujian susu segar. SNI 012782-1998/Rev.1992. Badan Standarisasi Nasional. Jakarta.

[10] Subronto. 1995. Ilmu penyakit ternak. Gadjah Mada University Press. Yogyakarta

[11] Sudjana. 1992. Metode statistika, Edisi Lima. Tarsito. Bandung
[12] Steel R.G.D. dan Torrie J.H. 1991. Prinsip Dan prosedur statistika. Gramedia Pustaka Utama. Jakarta.

[13] Surjowardjojo, Sarwiyono, Soejoseputro dan Setyowati. 1985. Manajemen sapi perah. Fakultas Peternakan. Universitas Brawijaya. Malang

[14] Dinas Peternakan Jakarta Barat. 2006. Rakitan teknologi budidaya sapi perah. www.disnak. jabarprov.go.id.

[15] Sarwiyono, Surjowardojo P. dan Susilorini T.E. 1990. Manajemen produksi ternak perah. Fakultas Peternakan Universitas Brawijaya. Malang.

[16] Hidayat, Efendi, Fuat dan Patyadi. 2006. Manajemen kesehatan perah. www.disnak. jabarprov.go.id.

[17] Taylor V. 2006. The warning signs of Mastitis: analyzing a combination of factors to decide when to treat. Ministry of Agriculture, Food and Rural Affairs. Ontario.

[18] Shiddieqy M. 2002. Memetik manfaat susu sapi. Departemen Produksi Ternak Fakultas Peternakan Unpad. 